\title{
Research on Application of High Pressure Jet Grouting Impervious Wall on Manmade Island
}

\author{
Bin $\mathrm{Li}^{1,2,3, a}$, Jian $\mathrm{Yu}^{1,2,3}$, \\ ${ }^{1}$ Tianjin Port Engineering Institute Ltd. of CCCC First Harbor Engineering Company Ltd., Tianjin,30 \\ 222 China.
}

${ }^{2}$ Key laboratory of port geotechnical engineering, ministry of communications. PRC.Tianjin, 30222 China.

${ }^{3}$ Key laboratory of port geotechnical engineering of Tianjin, Tianjin, 30222 China

aemail;lee_binbin@163.com

Key words: impervious wall; high pressure jet grouting; detection technology; seepage property; Abstract: High pressure jet grouting seepage technology has gained improvement, it is widely used in water conservancy project as its technical advantage, but because of construction environment of offshore manmade island is more complex than water conservancy project, so its detection and construction technology also need further research. Drilling a core and pressing water to test strength and seepage property of impervious wall in the sea. Through drilling core can detect pile continuity of engineering construction quality, and water pressure test can detect the permeability of the wall. But drilling core position should be at the middle of the pile cross-section circle radius is more advisable; The results show that seepage property of upper part of the high pressure jet grouting pile is obviously slightly better than down part .

\section{Introduction}

High pressure jet grouting technique has been widely used in water conservancy and hydropower engineering industry, the advantages of equipment and low cost are widely used in the field of foundation reinforcement and seepage control engineering, the reasonable test methods to ensure the pile quality meet the design requirement are the indispensable procedure of high pressure jet grouting pile. The high pressure jet grouting seepage engineering application in marine engineering building in the initial stage, and the marine environment is worse than inland waterway engineering environment, so the high pressure jet grouting pile construction technology and rigorous testing technology in offshore is more strict than inland project. This paper bases a high pressure jet grouting impervious wall in man-made island, discusses the technology of construction and quality test in offshore engineering construction.

\section{Project Summary}

The west side of an manmade island connected with sea crossing bridge, the east side connected with tunnels, linking to the tunnel, island is to realize the smooth transition between the sea bridge and tunnel, and meet the needs of the building layout on it. The island tunnel is divided into dark bury section and open section. Island is using large diameter steel tube inserted into the impermeable layer, formed the island of impervious wall structures, avoided constructing water foundation pit, which eliminate the foundation pit supporting structure. The dark bury of east Island is completed when the steel cylinder must be cut on the east side of island, so make the small island connected to the sea, this creates a condition for construction of channel E1, and at this the moment, there is $13.0 \mathrm{~m}$ high water pressure between the foundation pit of the island and sea water level. In order to prevent sea water infiltrate to the foundation pit of island which makes the foundation pit water level raised and affect construction inside of the foundation pit. An impervious wall need to be set up in the east of dark tunnel which constructed by high pressure jet grouting technology. Arrangement diagram of construction is shown in figure 1.

The impervious wall is made of many high pressure jet grouting piles, which is positively 
triangular distribution, pile spacing is $0.7 \mathrm{~m}$, pile top elevation is about $-12.5 \mathrm{~m}$, pile bottom elevation is $-24.5 \mathrm{~m}$. There is total 311piles that construction time began from May 3th, 2012, to May 19th, 2012.

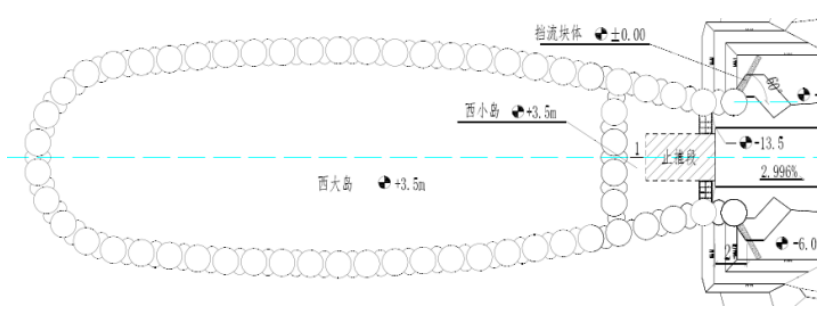

Fig. 1 Plan layout of sea island seepage project

The construction technology of the high pressure jet grouting pile impervious wall is using dual tube method, pile diameter is $1.0 \mathrm{~m}$. Plan layout of high pressure jet grouting impervious wall as shown in figure 2.

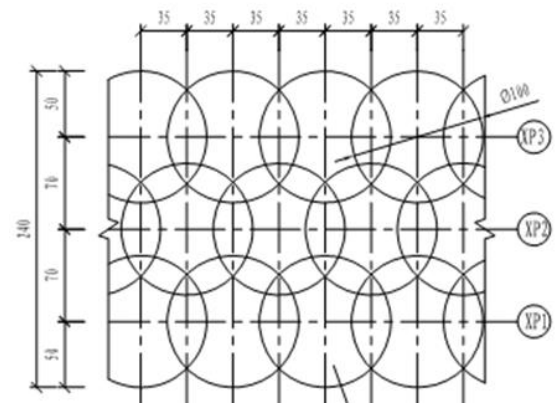

Fig. 2 Plan layout of high pressure jet grouting impervious piles

\section{Detection Method}

In order to detect the construction quality of impervious wall and prevention effect, four holes for detection were determined on the axis of the impervious wall decorate, test hole position as shown in figure 3, using the water pressure test method after drilling core for testing. There is a sample of $1.0 \mathrm{~m}$ back to the core during the whole section, recording photos and packing count into the book . Drilling sampling numbered as FS1, FS3, FS2 and FS4, borehole FS2 due to drilling tool problems, core samples are broken, no strength tests are carried out.

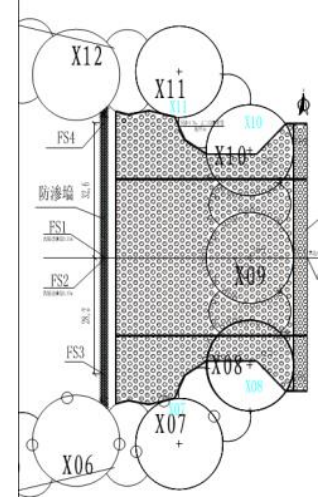

Fig. 3 Plan layout of water pressure test

Through drilling cores and pressuring water to detect the construction quality of impervious wall, and to get the permeability coefficient of impervious wall under designing head pressure difference, which can determine anti-seepage of impermeable layer.

3.1 Test Basis. (1) The drilling pressure water test procedures of water resources and hydropower engineering (SL31-2003);

(2) "Core" technical specification method to test concrete strength (CECS 03:20 07). 
3.2 Test Equipment. XY - 1 type Crawler drilling machine, Check water embolism, Pipe work, Measuring cylinder, Funnel, A stopwatch.

3.3 The Test Process and Data Processing. The four positions are selected as follow. The XY 1type crawler drilling machine drilled into the bottom elevation of $23.5 \mathrm{~m}$ (up from the pile bottom elevation $1 \mathrm{~m}$ ).

unconfined compressive strength test on core samples, FS1, FS3, FS4 .The thick sand layer in the location of the core sample average strength are: $7.47 \mathrm{MPa}, 4.30 \mathrm{MPa}, 13.82 \mathrm{MPa}$, clay layer position of the core sample average strength are: $2.85 \mathrm{MPa}, 3.37 \mathrm{MPa}, 2.10 \mathrm{MPa}$. The strength of sand layers is significantly higher than the strength of clay layer.

After completion of drilling core, pumping water to wash the hole, until the return water cleaning, start the installation of check water embolism, pipe connection work, and make the job control elevation $+13.5 \mathrm{~m}$, underground water level elevation is about $13.75 \mathrm{~m}$, head pressure of $262.5 \mathrm{kPa}$, meet the design requirements of $260 \mathrm{kPa}$.

With a measuring cup pull water into pipe mouths, record water volume in every 5 min, test can end when the maximum and minimum water volume is less than $10 \%$, take the final value as a calculated value, and according to the formula to calculate the permeability coefficient of the following:

$$
\mathrm{K}=\frac{\mathrm{Q}}{2 \pi \mathrm{HL}} \ln \frac{\mathrm{L}}{\mathrm{r}_{0}}
$$

3.4 Water Pressure Test Results. According to experimental data, and according to the formula (1) to calculate the test position pipe head loss, the permeability coefficient were $3.96 \times 10-6 \mathrm{~cm} / \mathrm{s}$, $5.65 \times 10-6 \mathrm{~cm} / \mathrm{s}, 8.55 \times 10-6 \mathrm{~cm} / \mathrm{s}, 4.96 \times 10-6 \mathrm{~cm} / \mathrm{s}$, belongs to low permeability layers. FS4 Calculation results of seepage test are shown in Table 1.

Table 1 FS4 Calculation results of seepage test

\begin{tabular}{|c|c|c|c|c|c|c|c|}
\hline $\begin{array}{c}\text { Orifice } \\
\text { elevation: }\end{array}$ & $-12.4 \mathrm{~m}$ & & $\begin{array}{l}\text { bottom } \\
\text { elevation: }\end{array}$ & $-23.5 \mathrm{~m}$ & \multirow{3}{*}{\multicolumn{3}{|c|}{$\begin{array}{l}\text { date: } 2012-7-2 \\
\text { pressure calculation zero elevation: } \\
-13.13 \mathrm{~m} \\
\begin{array}{c}\text { conversion formula } \\
\text { (units) }\end{array} \\
\end{array}$}} \\
\hline $\begin{array}{l}\text { Injection } \\
\text { elevation: }\end{array}$ & $\begin{array}{l}\text { head } \\
13.5 \mathrm{~m}\end{array}$ & & \multicolumn{2}{|c|}{$\begin{array}{c}\text { static head elevation: } \\
-13.75 \mathrm{~m}\end{array}$} & & & \\
\hline Symbol & project & unit & recor & alue & & & \\
\hline $\mathrm{Q}$ & traffic & $\mathrm{cm}^{3} / \mathrm{s}$ & 12.00 & $\mathrm{ml} / \mathrm{S}$ & \multicolumn{2}{|c|}{12.00} & \\
\hline $\mathrm{L}$ & length & $\mathrm{cm}$ & 7.1 & $\mathrm{~m}$ & \multicolumn{2}{|c|}{710} & \\
\hline $\mathrm{R}$ & Radius & $\mathrm{cm}$ & 54 & $\mathrm{~mm}$ & \multicolumn{2}{|c|}{5.4} & \\
\hline $\mathrm{H}$ & pressure & $\mathrm{cm}$ & 26.45 & $\mathrm{~m}$ & \multicolumn{2}{|c|}{2645.1} & \\
\hline \multicolumn{2}{|c|}{ Formula: } & \multicolumn{3}{|c|}{$\mathrm{K}=\mathrm{Q} * \ln (\mathrm{L} / \mathrm{R}) /\left(2 * \pi^{*} \mathrm{~L}^{*} \mathrm{H}\right)$} & $\mathrm{K}(\mathrm{cm} / \mathrm{s})$ & $4.96 \mathrm{E}-06$ & \\
\hline
\end{tabular}

\section{Conclusion}

Because of the influence of the construction process, the intensity of the jet grouting pile in the cross section distribution is not uniform, clear present a low center of pile strength and the intensity of the pile side is higher. Grouting pile core testing should be at the point of the pile cross-section circle radius position is more advisable, which can objectively reflect the average strength of the pile cross-section.

From pressure water test result, the upper part of the high pressure jet grouting pile permeable obviously slightly better than the next section. Reason is still in the process of construction work carried out in the same jet grouting parameters, the cement in different soil layer content is uneven, so as to increase the permeability. Sample permeability coefficient is not more than $10-5 \mathrm{~cm} / \mathrm{s}$. Inspection result shown that high pressure jet grouting technology used into wall quality is reliable; the anti-seepage effect meet the purpose of design.

The high pressure jet grouting pile is widely used in different geological situation, and with impervious function, has been more and more used in seepage control engineering, the physical and mechanical properties of foundation soil and pile quality jointly determine the seepage control 
effect, so for high pressure jet grouting impervious wall construction quality inspection can use drilling core pile continuity, and through hole water pressure test to test the permeability of it.

\section{Reference}

[1] WAN XiangHong, XING ZhiGuo, ZHU YanBao, et al. Application of Double-grout \& Double High-pressure Grouting Impervious Wall in Fine Silt Dam of Da ding zi shan Navitation-Power Junction [J]. port waterway Engineering, 2008, (6):58-58.

[2] CHI YuXiao. Research on construction technology of high pressure jet grouting impervious wall [J]. Inner Mongolia Water Resources, 2012, (3):42-43.

[3] HAN Lijun, WANG Zhuo, WU XiaoBin. Construction Technology of High Pressure Rotary Sprinkling Impervious Wall in a Cofferdam of Hydropower Station in Yunnan [J]. Exploration engineering (rock \& soil drilling and tunneling), 2007, 34(5):24-26.

[4] ZHANG LiXin, XIAO Qiang. The construction of high pressure jet grouting wall of the reverse regulation reservoir in West Xia Yuan [J]. yellow river, 2006, 28(7):57-58.

[5] TIAN YongQing, ZHANG ZhiRen. High pressure jet grouting impervious wall Daliang Reservoir Dam Foundation [J]. Haihe Water Resources, 1998, (5):30-31.

[6] SONG Zhi Bin, ZHANG JinChang, FENG QiZeng, et al. The Research and Application of High Pressure Rotary Jetting Technique for Leak Proofing and Soil Strengthening Engineering [J]. Exploration engineering (rock \& soil drilling and tunneling), 2003, (1):38-42.

[7] SUN MingXin. The Research on engineering characteristics of high pressure jet grouting pile [D]. Dalian University of Technology, 2000. 